\title{
PENGARUH PERMAINAN BOLA CERIA TERHADAP PERILAKU KERJASAMA ANAK DI TAMAN KANAK KANAK JABAL RAHMAH PADANG
}

\author{
Rahma Defy Chaniago ${ }^{1}$, Nurhafizah Nurhafizah ${ }^{2}$ \\ 1,2 Universitas Negeri Padang \\ e-mail: ${ }^{1}$ rahma31.defychan @ gmail.com, ${ }^{2}$ nurhafizah.is.87@gmail.com,
}

Diterima: 21 November 2019| Direvisi: 12 Desember 2019| Disetujui: 13 Desember 2019 (C)2019 Pendidikan Guru Raudhatul Atfhal Fakultas Agama Islam Universitas Islam Malang

\begin{abstract}
This article is written based on the results of research conducted based on the facts that occur in kindergarten Jabal Rahmah Padang, that the cooperative behavior of children has not yet developed due to lact of activities to train cooperative behavior in children. Learning activities in schools are carried out individually by the child, so that it affects the cooperative behavior of children. This study aims to determine the effect of cheerful ball play on the cooperative behavior of children. This research method uses a quantitative approach with a quasi-experimental design. Data collection techniques used are tests, and processed by the difference test (t-test). After the data is processed, it is seen that the children in the experimental class with a cheerful ball game have a higher average value than the control class with a block game. So it can be concluded that the cheerful ball game affects the cooperative behavior of children in kindergarten Jabal Rahmah Padang.
\end{abstract}

Keywords: Cheerful Ball Game; Cooperative Behavior; Children Of Kindergarten

\section{A. Pendahuluan}

Anak adalah individu yang unik yang tidak sama dengan individu lainnya. Anak usia dini merupakan manusia yang menjalani proses pertumbuhan dan perkembangan yang pesat, dan memiliki rentang usia yang sangat berharga dibanding usia-usia selanjutnya (Mulyasa, 2014:16). Menurut Mansur (2009:66) dalam Triyanti, dkk (2016:28) pendidikan anak usia dini adalah upaya pemberian kegiatan pembelajaran untuk menstimulasi, membentuk serta mengasah kemampuan dan keterampilan pada anak. Erikson (Krisnawati, 2014:46-47) menjelaskan bahwa manusia berkembang dalam tahap psikososial yang terlihat dari adanya keterkaitan antara hubungan pribadi dan kebudayaan sampai seseorang menjadi dewasa. Yusuf (2014:122) mengatakan perkembangan sosial adalah kedewasaan seseorang dalam berhubungan sosial. Perkembangan sosial juga berarti proses penyesuaian diri pada norma-norma kelompok, tradisi dan

This work is licensed under Creative Commons Attribution Non Commercial 4.0 International License Available online on: http://riset.unisma.ac.id/index.php/fai/index 
moral, serta saling berkomunikasi dan saling bekerja sama. Menurut Piaget dalam Musyarofah (2017:109) perkembangan sosial anak usia 4-6 tahun (Taman Kanakkanak) yaitu: 1) Usia 4 tahun, anak bekerja dengan 2 atau 3 kawan yang dipilih, dapat membersihkan alat permainan, 2) Usia 5 tahun, anak senang di rumah dengan ibu, membantu ibu dan senang pergi ke sekolah serta senang bermain dengan 2 atau 5 orang teman, 3) Usia 6 tahun, anak sudah mulai menjadi pusatnya sendiri, mementingkan diri sendiri dan antusias.

Dacholfany dan Hasanah (2018:98) menyatakan bahwa pada usia 5 sampai $\leq 6$ tahun anak sudah bersifat kooperatif dengan temannya, sudah mampu menunjukkan sikap toleran serta memahami peraturan dan disiplin. Menurut Helm \& Turner (1983:225) dalam Susanto (2017:28) ada 4 pola perilaku sosial anak, yaitu: 1) Kerja sama (cooperating), 2) Menghargai teman (altruism), 3) Berbagi kepada teman (sharing), dan 4) Membantu orang lain (helping other). Saputra, dkk (2005:51) dalam Susanto (2015:185) menyatakan bahwa pembelajaran kerja sama dapat memberikan beberapa manfaat diantaranya ialah bertambahnya sikap tanggung jawab anak terhadap diri sendiri maupun anggota kelompoknya, membantu teman yang memerlukan bantuannya, dapat bekerja sama dalam kelompok dan anak mampu berpendapat dengan mengutarakan segalanya kepada teman kelompoknya. Mayesty (1990) dalam Sujiono (2009:144) menjelaskan bahwa bermain merupakan aktivitas yang dilakukan sepanjang hari sebab bermain adalah hidup dan hidup adalah permainan. Pada umumnya, anak akan menikmati permainan kapanpun mereka memiliki kesempatan untuk bermain. Psikolog Turner dan Helmes dalam Heni (2010) dalam Nurhafizah dan Azlina (2015:91) mengatakan bahwa bermain sangat mempengaruhi perkembangan sosial dan kepribadian anak, bermain adalah kegiatan yang membantu anak untuk berhubungan dengan lingkungan sekitarnya, serta menunjukkan karakter anak. Munafiah, dkk (2018:224) menyatakan bahwa bola ceria merupakan permainan dan strategi pembelajaran atau kegiatan bermain dalam rangka untuk diterapkan dalam pembelajaran atau kegiatan bermain dalam rangka melatih kemampuan interpersonal pada anak, dimana kecerdasan interpersonal ini merupakan kecerdasan yang dimiliki seseorang ketika dia mampu menanggapi pandangan, perbuatan dan perilaku orang lain. Permainan bola ceria cocok digunakan pada anak Taman Kanak-kanak (TK) A dan B.

\section{B. Metode}

Berdasarkan permasalahan yang diteliti yaitu "Pengaruh Permainan Bola Ceria terhadap Perilaku Kerja Sama Anak di Taman Kanak-kanak Jabal Rahmah Padang", maka metode penelitian yang dipakai ialah pendekatan kuantitatif 
dengan jenis penelitian eksperimen. Sugiyono (2018:110) mengatakan metode eksperimen adalah metode yang digunakan ketika peneliti ingin menjalankan suatu percobaan untuk mencari pengaruh variabel perlakuan tertentu terhadap variabel hasil/output dalam kondisi yang terkendalikan.

Menurut Sugiyono (2018:166) instrumen penelitian adalah alat yang digunakan mengukur fenomena alam maupun sosial yang diamati menggunakan tes buatan guru yang disusun berbentuk tes-tes perbuatan. Arifin (2011:149) menjelaskan tes perbuatan berarti tes yang mengacu pada proses penampilan seseorang yang dilihat dalam bentuk perilaku, tindakan, dan perbuatan. Instrumen penelitian ini menggunakan tes buatan guru dengan format checklist dalam penilaiannya sesuai dengan kriteria penilaian, yaitu BSB (Berkembang Sangat Baik) skor 4, BSH (Berkembang Sesuai Harapan) skor 3, MB (Mulai Berkembang) skor 2, BB (Belum Berkembang) skor 1.

Teknik analisis data adalah membandingkan dua rata-rata nilai. Untuk melakukan analisis data perlu dilakukan uji normalitas memakai uji Liliefors dan uji homogenitas memakai uji Bartlett. Apabila sebuah data sudah berdistribusi normal serta bersifat homogen maka analisis data bisa dilakukan sesuai dengan teknik yang ditentukan, yaitu mencari perbandingan dengan rumus $t$-test (Syafril, 2010:176).

\section{Hasil dan Pembahasan}

Berdasarkan penelitian yang telah dilakukan, diperoleh data hasil pre-test dan post-test dikelas eksperimen (B1) dan kelas kontrol (Kelompok Safa) diolah menggunakan uji hipotesis, kelas eksperimen dengan permainan bola ceria dan kelas kontrol permainan balok. Kegiatan dilakukan 10 kali, 5 kali di kelas eksperimen dan 5 kali di kelas kontrol yang terdiri dari 1 pre-test, 3 kali treatment, dan 1 post-test. Dibawah ini adalah hasil pre-test dan post-test dengan pengujian $t$ test kelas eksperimen dan kontrol. Table 1. hasil Perhitungan Pre-test dengan Pengujian $t$-test

\begin{tabular}{|l|l|l|l|l|l|l|}
\hline No & Kelompok & $\mathbf{N}$ & Hasil Rata-rata & $\mathbf{t}_{\text {hitung }}$ & $\mathbf{t}_{\text {tabel }}$ & Keputusan \\
\cline { 1 - 3 } & Eksperimen & 12 & 41,75 & 1,1363 & 2,07387 & Ho diterima \\
\cline { 1 - 3 } & Kontrol & 12 & 37,75 & & & \\
\hline
\end{tabular}

Dari uji hipotesis didapatkan $t_{\text {hitung }}$ lebih kecil dari $t_{\text {tabel }}(1,1363<2,07387)$. Dilihat dari tabel di atas, $\mathrm{dk}\left(\mathrm{N}_{1}-1\right)+\left(\mathrm{N}_{2}-1\right)=22$ dengan taraf nyata $\alpha=0,05(5 \%)$ di dapat dari tabel 2,07387, maka hipotesis Ho diterima atau Ha ditolak. Dengan 
demikian, tidak ada perbedaan yang signifikan antara kemampuan awal anak di kelas eksperimen dan kontrol dalam mengembangkan perilaku kerja sama anak.

Table 2. Hasil Perhitungan Post-test dengan Pengujian t-test

\begin{tabular}{|l|l|l|l|l|l|l|}
\hline No & Kelompok & $\mathbf{N}$ & Hasil Rata-rata & $\mathbf{t}_{\text {hitung }}$ & $\mathbf{t}_{\text {tabel }}$ & Keputusan \\
\cline { 1 - 4 } 1 & Eksperimen & 12 & 79,83 & 3,11078 & 2,07387 & Tolak Ho \\
\hline 2 & Kontrol & 12 & 69,16 & & & \\
\hline
\end{tabular}

Dari uji hipotesis didapatkan $t_{\text {hitung }}$ lebih besar dari $t_{\text {tabel }}(3,11078>$ $2,07387)$. Dilihat dari tabel di atas, $d k\left(\mathrm{~N}_{1}-1\right)+\left(\mathrm{N}_{2}-1\right)=22$ dengan taraf nyata $\alpha=$ 0,05 (5\%), maka hipotesis Ha diterima atau Ho ditolak. Dengan demikian, terdapat perbedaan yang signifikan antara hasil post-test anak kelas eksperimen dan kelas kontrol dalam mengembangkan perilaku kerja sama anak.

Table 3. Perbandingan Hasil Perhitungan Nilai Pre-test dan post-test

\begin{tabular}{|l|l|l|l|l|}
\hline \multirow{2}{*}{ Variabel } & \multicolumn{2}{c|}{ Pre-test } & \multicolumn{2}{c|}{ Post-test } \\
\cline { 2 - 5 } & Eksperimen & Kontrol & Eksperimen & Kontrol \\
\hline Nilai Tertinggi & 50 & 46 & 92 & 79 \\
\hline Nilai Terendah & 33 & 25 & 71 & 46 \\
\hline Rata-rata & 41,75 & 37,75 & 79,83 & 69,16 \\
\hline
\end{tabular}

Berdasarkan tabel tersebut, tampak perbandingan hasil nilai pre-test dan nilai post-test. Pada pre-test nilai tertinggi kelas eksperimen yaitu 50 dan dan nilai terendah 33 dengan rata-rata 41,75 sedangkan nilai tertinggi kelas kontrol yaitu 46 dan nilai terendah 25 dengan rata-rata 37,75. Pada post-test nilai tertinggi kelas eskperimen yaitu 92 dan nilai terendah 71 dengan rata-rata 79,83 sedangkan posttest nilai tertinggi kelas kontrol 79 dan nilai terendah 46 dengan rata-rata 69,16. Perbandingan hasil perhitungan nilai pre-test dan post-test tampak bahwa nilai rata-rata post-test lebih meningkat dari nilai rata-rata pre-test setelah dilakukan treatment. Untuk lebih jelasnya dapat dilihat pada grafik berikut ini: 


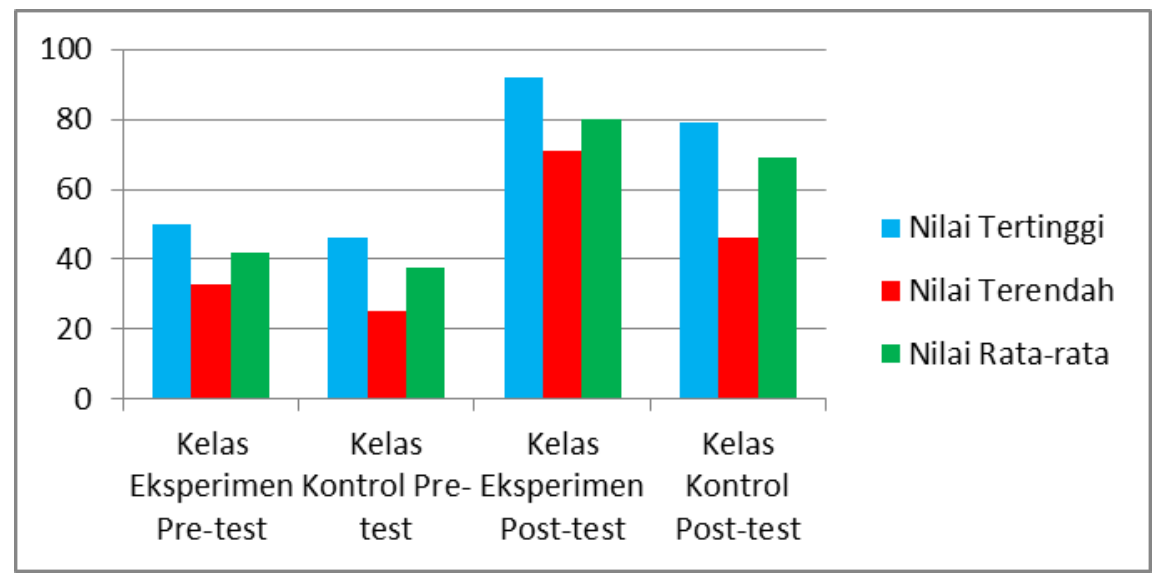

Grafik 1

Data Perbandingan Hasil Pre-test dan Post-test Perilaku Kerja Sama Anak Kelas Eksperimen dan Kelas Kontrol

Perkembangan sosial anak adalah macam mana anak mampu berkomunikasi dengan teman, orang dewasa, dan masyarakat luar supaya bisa menyesuaikan diri dengan baik sesuai yang diharapkan (Mayar, 2013:459). Dacholfany dan Hasanah (2018:95) menyatakan bahwa pada usia 5 sampai $\leq 6$ tahun anak sudah bersifat kooperatif dengan temannya, sudah mampu menunjukkan sikap toleran serta memahami peraturan dan disiplin.

Agusniatih (2015) dalam Nurhafizah dan Azlina (2016: 370) menyatakan bahwa "social emotional competence is something that must be understood and taught, because children are social beings who will live and adapt to the surrounding environment". Menurut Lwin (2008:197-198) dalam Fauziddin (2016:35) kemampuan sosial yang baik dapat dilihat ketika anak bisa berteman dan bersahabat dengan baik, bagaimana anak bisa dekat sama orang baru dan jarang memiliki konflik dengan temannya. Nurhafizah dan Azlina (2016: 370) menyatakan bahwa "they do not have a model have a model that can serve as an example in fostering social life, so often bring problems in socializing. Children who are not able to work, unable to adjust, unable to empathize, not able to abide by the rules and are not able to appreciate others will greatly affect the development of other children".

Yusuf (2014:125) mengatakan bahwa kerja sama (cooperation) adalah sikap bersedia bekerja sama dengan kelompok, artinya bagaimana seorang anak dapat di ajak untuk menyelesaikan suatu kegiatan bersama dalam suatu kelompok. Saputra, dkk (2005:39) dalam Susanto (2015:183) menyatakan bahwa kerja sama atau kooperatif adalah salah satu cara untuk melakukan ataupun menyelesaikan 
suatu kepentingan bersama dengan tujuan yang sama. Menurut Asma (2006:26) dalam Hidayati (2014:14) manfaat bekerja sama bagi anak yaitu: 1) Menumbuhkan rasa kebersamaan, 2) Melatih komunikasi dalam kelompok, 3) Mendorong keaktifan anak, 4) Menumbuhkan antusiasme, dan 5) Membantu anak agar berani mengemukakan pendapatnya.

Suryana (2016:187-189) menyatakan bahwa ada beberapa bentuk-bentuk tingkah laku sosial anak salah satunya adalah kerja sama (cooperation) yaitu tindakan bersedia bekerja sama dalam kelompok. Pada usia 2 atau 3 tahun sikap kerja sama anak belum berkembang, anak masih bersifat "self-centered". Pada usia akhir 3 tahun atau 4 tahun, anak sudah menunjukkan sikap kerja samanya dengan anak lain. Usia 6 atau 7 tahun kerja samanya sudah berkembang dengan baik lagi.

Saputra, dkk (2005:53) dalam Susanto (2015:185) mengatakan manfaat pembelajaran kerja sama adalah anak mencapai peluang yang lebih besar untuk berhubungan dengan anak lain, membantu anak menerima berbagai informasi dan pengetahuan sendiri, menumbuhkan kebiasaan anak untuk bekerja sama dengan anak lain dalam tim, menerima perbedaan yang terjadi dan membentuk pribadi yang terbuka, dan melatih anak untuk senantiasa aktif dan kreatif. Tujuan kerja sama anak usia dini menurut Yudha (2005:54) dalam Susanto (2015:186) yaitu: 1) Untuk menyiapkan anak supaya terlibat dalam dunia yang selalu berkembang, 2) Mengembangkan kemampuan bekerja sama dengan orang lain dalam berbagai situasi sosial, 3) Membentuk pengetahuan secara aktif dalam pembelajaran kerja sama, 4) Menguatkan korelasi antara anak dan diantara anak dengan guru.

Tedjasaputra (2003) dalam Nurhafizah dan Azlina (2015:86) menyatakan bahwa belajar bagi anak dilakukan melalui bermain. Dengan bermain memberikan peluang bagi anak untuk berinteraksi dengan lingkungan yang berpadu menjadi hasil pengalaman baru. Pengalaman di dapat anak ketika mereka mendapatkan kesempatan untuk berinteraksi dengan teman sebaya. Sujiono $(2007,8.5)$ dalam Nur $(2017,56)$ mengatakan bahwa bola merupakan media pembelajaran yang mampu mendorong anak secara aktif berkomunikasi dan terlibat dengan lingkungan fisiknya. Menggunakan permainan bola memungkinkan semua anak terlibat sehingga anak mampu merespon aktivitas dengan gembira. Munafiah, dkk (2018:224) mengatakan bahwa permainan bola ceria merupakan pembelajaran yang cocok untuk diterapkan dalam pembelajaran atau kegiatan bermain dalam rangka melatih kemampuan interpersonal pada anak, dimana anak mampu memahami pikiran, sikap, dan perilaku orang lain. Permainan bola ceria dapat mengembangkan berbagai perilaku sosial anak, diantaranya membangun sikap kerja sama, saling menghargai, tolong-menolong, ceria, aktif dan semangat, serta setia kawan dengan teman-temannya. 
Penelitian ini dilaksanakan di Taman Kanak-kanak Jabal Rahmah Padang sebagai kelas eksperimen dan di Taman Kanak-kanak Ananda Padang sebagai kelas kontrol. Penelitian ini menggunakan 5 butir instrumen sebagai titik tolak dalam melakukan penilaian terhadap perilaku kerja sama anak. Pada saat peneliti menggunakan permainan bola ceria di kelas eksperimen (B1) di Taman Kanakkanak Jabal Rahmah Padang, anak terlihat antusias dan semangat. Pada saat peneliti mulai mengenalkan permainan bola ceria kepada anak, sebagian anak terlihat sangat antusias, dan anak mau mengikuti apa yang di instruksikan oleh peneliti. Ketika anak-anak di ajak keluar kelas anak-anak sangat senang sehingga agak sulit bagi peneliti untuk mengontrol anak, namun setelah dijelaskan dengan baik akhirnya anak bisa mengontrol rasa senangnya. Disaat permainan dimulai, anak-anak terlihat saling membantu dalam menyelesaikan permainan. Sedangkan di kelas kontrol (Kelompok Safa) di Taman Kanak-kanak Ananda Padang, dengan menggunakan permainan balok dalam mengembangkan perilaku kerja sama anak. Namun anak tidak begitu antusias karena permainan balok merupakan permainan yang sudah sangat sering dilakukan, sehingga menimbulkan kebosanan pada diri anak. Dan dalam kegiatan permainan balok, hanya sebagian anak saja yang ikut andil dan bekerja sama dalam menyelesaikan kegiatan.

Berdasarkan hasil penelitian yang peneliti lakukan tentang permainan bola ceria terhadap perilaku kerja sama anak di kelas eksperimen lebih berpengaruh dari pada hasil perilaku kerja sama anak di kelas kontrol. Maka disimpulkan bahwa permainan bola ceria berpengaruh untuk mengembangkan perilaku kerja sama anak.

\section{Simpulan}

Penelitian yang dilakukan membuktikan ada perbedaan nilai rata-rata, kelas eksperimen (B1) di Taman Kanak-kanak Jabal Rahmah Padang yang dilakukan dengan menggunakan permainan bola ceria lebih tinggi daripada kelas kontrol (Kelompok Safa) di Taman Kanak-kanak Ananda Padang dengan permainan balok. Nilai rata-rata kelas eksperimen yaitu 79,83 dan kelas kontrol yaitu 69,16. Hasil uji hipotesis diperoleh hasil thitung $>t_{\text {tabel }}$ yaitu 3,11078 $>2,07387$ dengan taraf signifikan $\alpha=0,05$ (5\%). Sehingga dapat disimpulkan bahwa permainan bola ceria berpengaruh dalam mengembangkan perilaku kerja sama anak di Taman Kanakkanak Jabal Rahmah Padang.

\section{Daftar Rujukan}

Arifin, Zainal. 2011. Evaluasi Pembelajaran. Bandung: Remaja Rosdakarya 
Dacholfany, Ihsan dan Uswatun Hasanah. 2018. Pendidikan Anak usia Dini Menurut Konsep Islam. Jakarta: Amzah

Fauziddin, Moh. 2016. Peningkatan Kemampuan Kerja Sama Melalui Kegiatan Kerja Kelompok Pada Anak Kelompok A TK Kartika Solo Kabupaten Kampar. Jurnal Paud Tambusai (no.1, Vol.2)

Hidayati, Wahyu. 2014. Upaya Meningkatkan Kemampuan Kerja Sama Melalui Permainan Tradisional Pada Anak Kelompok A TK ABA Ledok I Kulon Progo Tahun Ajaran 2013/2014. Universitas Negeri Yogyakarta. (Https://eprints.uny.ac.id/13562/1/wahyu\%hidayati_1111124735.pdf)

Mayar, Farida. 2013. Perkembangan Sosial Anak Usia Dini Sebagai Bibit Untuk Masa Depan Bangsa. Jurnal Al-Ta'lim: Jilid 1 (No. 6) hlm 459

Mulyasa. 2014. Manajemen Paud. Bandung: PT Remaja Rosdakarya

Munafiah, dkk. 2018. Strategi Pembelajaran Anak Usia Dini Berbasis Multiple Intelligences. Jawa Tengah: Penerbit Mangku Bumi (http://books.google.co.id)

Musyarofah. 2017. Pengembangan Aspek Sosial Anak Suia Dini Di Taman Kanakkanak ABA IV Mangli Jember Tahun 2016. INJECT: Interdisciplinary Journal Of Communication (No. 1, Vol.2) Hlm (107-109)

Nurhafizah dan Azli Kosnin. 2016. The Development of Children's SocialEmotional Competences: A Case Study In UNP's Labschool-Kindergarten, Padang Indonesia. Advances In Social Science, Education And Humanities Research (ASSEHR): Atlantis Press (Vol 58) Hlm (370-371)

Nurhafizah dan Azlina Moh. Kosnin. 2015. Implementasi permainan tradisional indonesia di taman kanak-kanak kota padang. Jurnal ilmiah ilmu pendidikan: pedagogi (vol. xv, no. 1) hlm (86-91)

Sugiyono. 2018. Metode Penelitian Kuantitatif. Bandung: Alfabeta

Sujiono, Yuliani Nurani. 2009. Konsep Dasar Pendidikan Anak Usia Dini. Jakarta: PT Indeks

Suryana, Dadan. 2016. Pendidikan Anak Usia Dini. Stimulasi Dan Aspek Perkembangan Anak. Jakarta: Prenadamedia Group

Susanto, Ahmad. 2015. Bimbingan Dan Konseling Di Taman Kanak-kanak Edisi Pertama. Jakarta: Prenadamedia Group 
Rahma Defy Chaniago, Nurhafizah

Susanto, Ahmad. 2017. Pendidikan Anak Usia Dini Konsep Dan Teori. Jakarta: Bumi Aksara

Syafril. 2010. Statistika. Padang:Sukabina Press

Triyanti, Enda, dkk. 2016. Meningkatkan Kemampuan Bekerja Sama Melalui Bermain Simbolik. Jurnal Ilmiah Potensia (No. 1, Vol. 1)

Yusuf, Syamsu. 2014. Teori Psikologi Perkembangan Erik H. Erikson Dan Manfaatnya Bagi Tugas Pendidikan Kristen Dewasa Ini. Kurios: Jurnal Teologi Dan Pendidikan Agama Kristen. (No. 2, Vol. 2) 